\title{
An Islamic Scriptural Anthropology
}

\author{
Marie Nuar \\ Pontifical University of St. Thomas, Rome, Italy
}

\begin{abstract}
A proper way of understanding humanity is not possible without knowing where humanity is from and why he is here. While there are a number of Qur'anic verses that speak of humanity's creation and mission, the one that speaks most clearly of the telos of that creation is Al-Dhariyat 56, which reads, "I have not created jinn and mankind except to serve me." A summary examination of some of the prominent Qur'anic commentators and their interpretation of the verse give insight into the understanding of the telos of humanity's creation according to the Qur'an. The examination of the commentaries reveals certain recurring themes. Through the revelation of the Qur'an, one is able to know humanity's place and mission in the created world and thereby act accordingly.
\end{abstract}

Keywords: Islamic anthropology, Qur'ānic commentary, purpose, tafsīr, worship, worldview

\section{Introduction}

To understand ethical and societal systems, such as human rights, religious freedom, and justice and duties, it is beneficial to first grasp the understanding of human nature that is proposed by a particular group. For one's worldview is grounded in one's anthropological understanding. This article summarizes the views of 12 Islamic commentators on the verse of the Qur'ān, "I have not created jinn and mankind except to serve me," (al-Dhäriyāt (51): 56) which presents an understanding of human nature. The commentaries mentioned cross the Sunnī and Shīa divide of Islam; they span the history of Islam from the classical period to the modern; and they include various schools of thought. With such variety there is bound to be some variation on the interpretations offered and the methods used. But one detects more similarities than one might at first think.

\section{Approaches to the Text}

Many of the commentators rely on hadīth to interpret the Qur'ān. Ṭabarī makes sure he cites his sources when citing a hadith. He first groups the hadith by how it interprets the verse, then concludes by briefly stating which of the interpretations he agrees with giving a short explanation. Qurtubî, unlike Tabarī, was not concerned with the isnād of the hadìth, but only the content, which he used to better understand the meaning and implication of the law. Where Tabarī merely reported the hadīth, Qurtubî is more directly analyzing the verse and using the hadìth to support his understanding of it. For Qurtubi the explanation he wants to give is primary and the matn or text of the tradition is used in a supportive role. Ibn Kathīr, who focused on history and traditions, offers a pithy interpretation of the verse before citing the ahădìth that support his interpretation. Suyūțī has no direct commentary. Rather, he arranges the ahâa $\bar{t} t h$ to create a narrative that explains the verse. Shawkānī, although advocating ijtihād, still made use of the hadìth. Like Qurtubỉ's commentary, for Shawkānī

Marie Nuar, Sacred Theology Doctorate, Ecumenical and Interreligious Studies Section, Pontifical University of St. Thomas. Correspondence concerning this article should be addressed to Marie Nuar, 9213 Stonewall Rd., Manassas, VA 20110 USA. 
the argument is primary and the hadīth are used to show the support for his interpretation in the traditions.

Many of the modern commentators believed that the traditional commentators did not understand what they explained. They sought to do away with taqlid and the accretions of time and return to a simpler and better understood analysis of the Qur'ān. The scholarly sources were not entirely ignored but were used sparingly and only where it would help the popular understanding. Abū al-Thana Baghdādī explains the meaning of the text by explaining the Arabic language itself and independent opinions. He seeks to use the Qur'ān itself to guide his interpretation more than the hadith. Like the other modern writers, the commentary is lengthier than the average traditional ones. Baghdādī does not just give his interpretation, but shows which other Qur'ānic verses support his interpretation and seeks to explain the thought process that led to his conclusions. Mawdūdī is specifically writing for the non-specialist, and therefore moves away from the use of the Qur'ânic sciences, which would mean nothing to his readers. He seeks to explain the Qur'ān in an easily understood way. He does not explicitly use the traditions, but does incorporate the ideas found in them into his commentary. It is more conversational than other commentaries and makes an effort to define what the term ibādāt means. His simpler approach enabled those who were literate, but not studied in the Qur'ānic sciences, to better understand the text. Similarly, Quț wrote his tafsir , ignoring what had been the normative approach to the text and sought to understand the text from the text itself aimed at making the text accessible to all. Despite his lack of training in the religious sciences, his simpler approach has helped to make his commentary one of the most widely read ones throughout the modern Muslim world.

Besides the heavy reliance on hadith or the focus on the text itself without any assistance, a small number of the commentators used a more rationalistic approach. Zamakhsharī, a Mutazilite, uses the more rationalistic approach to the text which they were known for. He seeks to analyze the text through his knowledge of the Arabic language that he was known for. Rāzì's appreciation of philosophy and rationalist theology show in his commentary, as he attempts to analyze each aspect of the verse and its implications. Ṭabațābāî, like Rāzī, had a deep appreciation for philosophy that is evident in his commentary. Ṭabațābāî, in addition to analyzing all the possible implications of the verse, also focuses on the grammar and how the grammar effects the interpretation. He is an outlier of modern interpretation in his use of the traditional Qur'ānic sciences.

\section{Understanding the Question}

A distinction must be drawn when discussing the purpose of mankind's creation. There are two ways to speak of the purpose of mankind's creation. The first is from God's perspective. What was God's reason for creating mankind? The second is from mankind's perspective. What was mankind created for? Said another way, what was mankind created to do? Very few of the commentators ever address the first point.

Of the commentators studied here, only Rāzī and Ṭabațābāì address this question. Rāzī’s answer is that God, who is "perfect in Himself" and therefore needs neither perfection nor benefits, acts for no purpose at all in creating mankind. In support of this view he cites the Qurān, "God does what He will" (Q. 14: 27) and "He shall not be questioned as to what He does." (Q. 21: 23). For Rāzī, God created mankind because He willed it and, since He has not revealed why he willed it, the reason cannot be known. Rāzī articulates this position in opposition to the Mutazila who "say the actions of God Almighty are for a reason," although Rāzī's argument does not per se contradict the Mutazilite position. God has a reason for what He willed, but the reason is not God's own perfection or from outside of Him and mankind does not know what it is. Tabațābāî, the only other commentator surveyed here who is also interested in philosophy, is also the only other commentator surveyed 
who addresses this question. Like Rāzī, he recognizes that God lacks nothing and so does not need mankind for His own perfection. Unlike Rāzī though, he recognizes that "an action which has no meaning for the actor is incoherent nonsense. One can conclude from this that the Almighty acts purposefully, possessing a purpose which He has not revealed."

\section{Commonalities}

Despite all the differences between the commentators, there is almost universal agreement that the purpose of mankind's creation was so that mankind would worship and serve God. For Ṭabarī, the verse indicates that mankind is created "to submit to Me through worship." Zamakhsharī, too, acknowledges that mankind was created to worship: "I did not make the jinn and mankind except for worship." Rāzī states that: "The reason for creating mankind was worship." Qurțubī’s interpretation is more in line with Ṭabarı̄’s, meaning that mankind is created to be subjected to God: "To serve is demonstrated through worship and servitude; and worship is rooted in obedience and humility...For the meaning of 'to worship' is to be 'subjected to', 'obey' and 'worship'." Ibn Kathîr declares the meaning as: "I only created them [mankind] in order to command them to worship me, not because I have any need of them," which is similar to Rāzī's declaration discussed earlier that God is perfect and does not need mankind. Tafsīr al-Jalālayn rephrases the verse in order to make it clear: "I did not create the jinn and mankind except that they may worship Me." Suyūțī, too, echoes this purpose in his citation of the hadīth: "Ibn Abī Shaybah based on Abī al-Jawzā educed from the verse that God teaches: I blessed them and I fed them. I have not created them except to serve."

The modern commentators do not swerve from this fundamental interpretation. Shawkānī interprets it as, "He had created them for nothing other than worship." Baghdādī does not just state that mankind was created for worship but shows the relation between the two: "Worship, if it is not the objective demanded of creation, according to the evidence noted, then the Almighty and Glorious did not create the jinn and mankind for that purpose, that is to say, for the purpose of [worship] from them." Mawdūdī emphasizes that God created mankind and mankind should therefore serve Him: "I have not created them for the service of others but for My own service. They should serve Me, for I am their Creator." Quṭb is more verbose than the others, but his message is identical:

There is a clear objective for the existence of humans and jinn on earth. This objective is represented in a task: whoever fulfills it achieves the objective of his existence, and whoever neglects it leads a life without purpose or objective... This task which binds humans and jinn to the law of the universe is worship or servitude to God.

Ṭabațābāī declares that it is rather clear that mankind was created to worship: "No doubt, it is obvious to him [mankind] that the purpose of creation is purposeful worship. Meaning that they are to be worshipers of God, not be worshipped."

\section{What Is Mankind's Purpose?}

All of the commentators surveyed agree that mankind was created to worship God. Given the verse itself it would be difficult to argue otherwise. Aside from agreement on the purpose of mankind's existence, there are various statements that each of the commentators emphasizes which relate to mankind's purpose or are derived from it.

Both Baghdādī and Tabațābāî point out that mankind is naturally disposed to worship. According to Baghdādī: 
They were created in a perfect condition, which predisposed them to worship. Given that the Almighty bestowed intelligence on them and created for them interior and exterior senses and the like for the purpose of being prepared, He is making His creation intentionally for [worship]...[w]ithout doubt, they were created so that God would receive worship from them.

For Baghdādī, what set mankind apart, that is his intelligence and sensations, are the very things that indicate his disposition toward worship. According to Baghdādī there can be no excuse for not worshipping, since mankind's nature disposes him to that purpose. Tabațābāì agrees with Baghdādī that mankind is disposed to worship in his very creation: "The purpose in the creation of the jinn and mankind is found in their creation, given their suitability for worship and predisposition towards it."

Whereas Baghdādī and Ṭabațābāî believe that all mankind was created disposed to worship, both Qurțubī and Shawkānī argue that not all mankind was created for that purpose. They both apply the example that young children and mad people are not required to worship in order to demonstrate that, although the verse is general, God knew in His mind the particulars of who would worship. As Qurțubī states: "that the particulars of who would worship Him were already in the mind of God...[w]hoever was created for Gehenna does not believe creation was intended to bring about worship, for the verse's logic pertains to those who believe." Shawkāni gives a very similar statement, namely that "the particulars of who would worship were already in the mind of God Almighty. His general purpose is [achieved] by means of the particulars.” Both Qurțubī and Shawkānī cite the Qur'ānic verse, "We have created for Gehenna many jinn and men" (Q. 7: 179) in order to support their interpretation. For as Shawkānī declares: "Whoever was created for Gehenna does not believe creation was intended to bring about worship." Baghdādī cites the same verse to indicate not that God's purpose was to send them to Gehenna, but that it was the desire of the disobedient to be sent to Gehenna.

One also finds among the commentators those who address the position of non-worshippers. Just because some from among mankind do not worship it does not follow that mankind was not created for worship. As Maḥallī explains in the Tafsīr al-Jalālayn,

the fact that disbelievers do not worship [God] does not contradict this [statement], since a purpose does not have to be realized [in an act, for it to be valid], as when you may say: 'I sharpened this pencil in order to write with it', even though you might not actually write with it.

Baghdādī phrases it in a different manner: "That some of them are held back from achieving this does not preclude the fact that this is the ultimate objective." For him those who fail to worship only help to prove mankind's purpose by its absence in their lives: "The Divine will for the purpose appears in the sources, although the absence [of worship] is a perceived reality." Rāzī, likewise, agrees that the circumstances of the unbelievers bear out the teaching that mankind is created for worship: "Seeing the circumstances of the unbeliever it is clear [that creation is for worship]." Not only do those who do not worship not serve to contradict the purpose for which mankind was created, but, by their lives, they prove it.

For Tabarī mankind is created to submit to God's commands. Their submission is achieved through worship. While some may choose not to worship there is no possibility of avoiding submission. For Tabarī everyone will submit; it is simply a decision whether they will "decide to worship willingly or unwillingly." No one can turn aside. Others, while not articulating the connection so clearly, see submission to God and worship inextricably linked. Qurțubī, citing a hadìth on the authority of Alī b. Abī Ṭaḷ̣a from Ibn Abbās, declares that "to worship" means "to acknowledge Him with worship willingly or unwillingly" Both Ibn Kathīr and Suyūṭi cite the same hadìth. 
Mawdūdī uses the expression that the body worships God involuntarily in order to encourage mankind to worship voluntarily: "They should serve God voluntarily just as every particle of their body is serving Him involuntarily in the sphere where they have not been granted any freedom." Zamakhsharī emphasizes man's free worship, going so far as to state that forced worship is not profitable.

His desire was that they worship Him freely, not out of compulsion, because He created them capable of thought. Some of them choose to neglect worship along with its purpose. If worship were profitable through force and coercion, then it would be found in all of mankind.

Mawdūdī simply highlights this freedom:

On the earth only the jinn and men have been granted the freedom that they may serve Allāh within their sphere of choice if they so like; otherwise they can turn away from Allāh's service as well as serve others beside Him.

Baghdādī not only speaks of the freedom to choose to worship that mankind possesses, but connects it with a particular nobility that mankind possesses: "It is clear that this worship was intended to be freely given, more than the permanent subjection of the rest of creation, which is an indication of their nobility amongst created things."

Rāzī speaks of mankind's nobility, but links it to sincere worship, not to the freedom that is given to mankind: "Therein He declares:

Surely the noblest among you in the sight of God is the most god-fearing of you" (Q. 49:13)... because if one is God-fearing then he worships and acts sincerely. From this it is necessary to conclude about existence that it enables and strengthens, like a thing whose lesson is advantageous to one.

Mankind's worship of God is advantageous to himself. Elsewhere, in speaking about reminding mankind of the need for worship Rāzī states: "So remind them about it and advise them that everything else is a waste of time." Zamakhsharī links together all that is profitable to worship: "For nothing is profitable among mankind except with worship." Ibn Kathīr declares "there is no benefit for idolaters." Suyūṭī cites a hadīth from Abū Hurayra wherein mankind is given the following order: "Devote yourself to My worship, I will fill your heart with freedom from want and satisfy your needs. If you do not do so, I will fill your heart with concerns that cause forgetfulness and not satisfy your needs." Mankind benefits from the worship he offers to God. A number of the commentators speak of mankind as being disposed to either misery or happiness, following from whether they worshipped or not. Ṭabarī, Qurțubī, Suyūțī, and Shawkānī all cite the same hadīth transmitted by Zayd b. Aslam that the verse under discussion teaches: "He [mankind] was naturally disposed towards both misery and happiness."

There are two other purposes that some of the commentators speak of when interpreting the verse. The first is that mankind is created to know and inform the rest of mankind about God's tawhīid. Rāzī declares this is part of the purpose of mankind's creation, stating that the meaning of revelation was so that mankind would know God. Qurțubī cites a tradition from Mujāhid expressing that mankind is created to know God in His being and oneness. When the verse says: "except to serve Me" it really means: "except to know Me." Shawkānī citing the same traditions writes that: "Mujāhid declares that the meaning is: except to know Me...because if He did not create them, His being and oneness would not be known." Baghdādī also considers the purpose of creation in knowing God, declaring: "For surely He created them in order to remember His splendor." The second is that articulated by Quțb, who does not view mankind's vicegerency as only a means for worshipping God and fulfilling His commands, but of helping to effect worship on earth: 
Being in charge of the earth is then the main function of human beings...In doing so, man puts in effect God's will to use and develop the earth so as to ensure steady progress. Man's vicegerency also involves the implementation of God's law so that human society can be set on the proper foundation, one that is in harmony with the law governing the universe.

Mankind's purpose is not just to know God himself but to ensure that human society does as well.

\section{What Does Worship Really Mean?}

Not all the commentators believe that it is necessary to define what worship entails. Many find it sufficient to declare that mankind is created to worship, serve, and submit to God. There are some who do seek to define what that worship is for either clarity or thoroughness. Rāzì declares that worship is "the exaltation of the law of God and the loving care of the creation of God." Qurțubi tells his readers that "the meaning of "to worship" is to "be subject to", "obey" and "worship". Shawkānī expresses it as stating that: "The meaning of worship is in the language of humility, submission, and obedience." Baghdādī distinguishes between the purpose of worship which is subjection and what it is, which is the profession of God's unity: "The purpose of worship is self-abasement and to obey with subjection...all worship in the Qur'ān is the profession of monotheism."

Both Mawdūdī and Quțb seek to distinguish "worship" from "ritual". Mawdūdī states that

The word ibādāt (service, worship) in this verse has not been used in the sense of only prayer, fasting and other kinds of such worship so that one may understand that the jinn and men have been created only for performing the Prayer, observing the Fast and for praising and glorifying Allāh. Although this sense also is included in it, this is not its complete sense. Its complete sense is that the jinn and men have not been created for the worship, obedience and carrying out of the orders of any other but Allāh.

Quṭb likewise seeks to draw the same distinction. "Worship" is broader than just observing the rituals:

An essential requirement of worship, in its proper and full sense, is that man should fulfill the duties of his position that places him in charge of the earth. He should achieve the best results he can in discharging his duties, while at the same time look for no personal benefit.

For Tabațābāī proper worship entails knowledge of one's actions:

This is the connotation of the explanation for intelligent worship, that is to say, worship with the knowledge of what is taking place. The true sense of worship is the ultimate purpose of creation, so that the worshipper himself ceases to be and in everything points towards his Lord.

Ṭabațābāì's understanding of worship differs significantly from that of Mawdūdī and Quṭb. For Ṭabațābāī, it is not simply the actions that one does, but also, includes the idea of losing oneself in God.

\section{Conclusion}

From the commentators surveyed above one reaches the conclusion that they all explain the verse to mean that mankind is created to worship. Suyūțī, Baghdādī, and Ṭabațābāī believe all mankind are naturally disposed to worship, while Qurțubī and Shawkānī believe that the verse only applies to the particular individuals God had in mind whereas others were created for Gehenna. Rāzī, Jalālayn, and Baghdādī explain that those who do not worship do not negate that statement that mankind was created for worship. Tabarī, Qurțubī, Ibn Kathīr, and Suyūțī emphasize that mankind must submit to God either willingly or unwillingly, whereas Zamakhsharī, Baghdādī, and Mawdūdī emphasize mankind's freedom. Baghdādī connects mankind's freedom to worship or non-worship with a greater dignity amongst God's creation. Rāzī, Qurțubī, and all the modern commentators 
make an effort to define what "worship" actually means. It is only Qurțubī, Shawkānī, and Baghdādī who mention the purpose of worship as being to know and acknowledge God's oneness. Rāzī and Ṭabațābāī are the only ones who address the reasons God might have had for creating mankind. Despite the centuries and the theological views that separate these commentators, their interpretation of this verse is in many ways remarkably similar.

\section{References}

abābāī, Sayyid Muhammad Hasīn al-. (1977). al-Mīzān fĩ Tafsīr al-Qurān (Vol. 18). Tehran: Dār al-Kitab. abarī, Abū Jafar al-. (1954). Jāmi al-Bayyān an Tawūl Ay al-Qurān (Vol. 11). Cairo: Dār al-Maārif.

Alūsī, Abū al-Thanāal-. (1926). Rūh al-Maānī. (Mamūd Shukrī al-Alūsī al-Baghdādī, Ed.). (Vol. 9). Cario: Idāra al-abā al-Manīīī.

Ibn Kathīr, \& Imād al-Dīn. (1980). al-Tafsīr al-Qurān al-Aīm (Vol. 6). Beirut: Dār al-Fikr.

Maallī, Jalāl al-Dīn al-, \& Abd al-Raman Jalāl al-Dīn al-Sūyūī. (n.d.). Tafsīr al-Qurān al-Karīm l-limāmīn al-Jalālayn. Cairo: Dār Iyā al-Kitāb al-Arabīa.

Mawdūdī, Abul Alā. (2014). The meaning of the Qurān. (Ch. Muhammad Akbar, Trans.; A. A. Kamal. Lahore, Ed.). Pakistan: Islamic Publications, n.d. Retrieved August 5, 2014, from http://www.englishtafsir.com/Qurān/51/index.html

Qub, Sayyid. (2009). In the shade of the Qurān: Tafsir fi Zilal al-Qurān. (Adil Salahi, Trans. \& Ed.) (Vol. 16). n.p: The Islamic Foundation, 2009. Retrieved October 2, 2014, from http://tafsirzilal.wordpress.com

Qurubī, Abū Abd Allāh al-. (1967). al-Jāmi li-Akām al-Qurān. (Amed Abd al-alīm al-Burdūnī, Ed.) (Vol. 17). Cario: Dār al-Kitāb al-Arabī li-ibāa wa-l-nashr.

Rāzī, Fakhr al-Dīn al-. (1935). al-Tafsīr al-Kabìr (Vol. 14). Cairo: al-Mabaa al-Bahīya al-Mirīya.

Riā, Muhammad Rashīd. (1954). Tafsīr al-Qurān al-ikīm al-Mushtahir b-ism Tafsīr al-Munār. Cairo: Dār al-Manār.

Shawkānī, Ibn Muammad al-. (1997). Fat al-Qadīr al-Jāmi Fannī al-Riwāya wa-l-Darāia min ilm al-Tafsīr (Vol. 5). Cairo: Dār al-Hadìth.

Suyūī, Abd al-Raman Jalāl al-Dīn al-. (1990). Al-Dur al-Manthūr fì Tafsīr al-Mathūr. (Vol. 6). Beirut: Dār al-Kitab al-alumīa.

Zamakhsharī, al-. (1953). al-Kashāf an aqāiq al-Tanzīl. (Vol. 4). Cairo: al-Maktaba al-Tijāriyya al-Kubrā. 